\title{
MENYATUKAN PENETAPAN 1 RAMADLAN, SYAWAL DAN DZULHIJJAH DI INDONESIA
}

\author{
Ahmad Wahidi \\ Fakultas Syari'ah UIN Maulana Malik Ibrahim Malang \\ Email:Wafiqillah@yahoo.com
}

\begin{abstract}
Abstrak
Determining to begin and to end fasting leads to disintegration conflict among muslims. In this paper, the root of the debate of the difference to determine qamariyah calendar will be discussed and to be found the solution quickly and accurately. There are two approaches that must be applied in integrating the beginning of qamariyah calendar in Indonesia; methodological approach and authority approach. However, the second approach should be implemented firstly to realize the integrity of the qamariyah calendar determination in order it can be accepted lawfully and scientifically.

Penyatuan waktu untuk memulai dan mengakhiri ibadah puasa ramadlan mengarah pada konflik disintegrasi pada komunitas muslim. Dalam tulisan ini, akan diulas tentang akar perbedaan penetapan awal bulan qamariyah kemudian dicarikan sebuah solusi yang cepat dan akurat. Ada dua pendekatan yang harus dilakukan dalam upaya penyatuan awal bulan qamariyah di Indonesia yakni pendekatan metodologis dan authority (kekuasaan). Namun untuk percepatan terwujudnya persatuan penetapan awal bulan qamariyah maka pendekatan yang kedua harus diutamakan terlebih dahulu sebelum pendekatan pertama membuahkan hasil yang bisa diterima secara syar'iyah dan ilmiah.
\end{abstract}

Kata Kunci:Hisab rukyat, Dialektis Metodologis, Single Authority

Seiring dengan perkembangan dan kemajuan zaman maka problematika di setiap sektor dan bidang semakin kompleks. Ini juga terjadi dalam bidang ilmu pengetahuan, dalam hal ini adalah ilmu falak terutama dalam ranah aplikatifnya. Dari empat materi dalam ilmu falak, ${ }^{1}$ yang paling tumbuh subur problem atau permasalahan adalah penentuan awal bulan qamariyah terutama awal Ramadlan, Syawal dan Dzulhijjah walaupun sebenarnya tiga materi lainnya juga ada problem atau permasalahan.

Boleh dikatakan bahwa problem penentuan awal bulan qamariyah adalah problem klasik yang sampai detik ini tidak kunjung terselesaikan. Dahulu di era tahun $70-80$ an perdebatan penetapan awal bulan hanya terjadi pada dua organisasi keagamaan terbesar di Indonesia yakni NU dan Muhammadiyah di mana perbedaan penetapan 1 Ramadlan, Syawal dan Dzulhijjah biasanya hanya terpaut satu hari namun kini perbedaan penetapan awal bulan-bulan tersebut bisa menjadi lebih dari 3 hari yang berbeda-beda. Hal ini disebabkan karena banyaknya aliran-aliran dan organisasi keagamaan di Indonesia yang memliki cara

4 materi pokok dalam ilmu falak : arah kiblat, waktu shalat, awal bulan / kalender dan gerhana atau metode serta kriteria penetapan awal bulan yang berbeda-beda dan masing masing mengklaim dan meyakini metode merekalah yang paling benar dan sesuai dengan tuntunan Al-Qur'an dan Hadits Nabi.

Indonesia memang negara yang kaya akan keanekaragaman termasuk dalam penetapan awal bulan qamariyah utamanya Ramadlan, Syawal dan Dzulhijjah yang berbeda-beda. Di satu sisi, perbedaan tersebut merupakan indikasi bahwa perkembangan ilmu falak atau hisab rukyat di Indonesia mengalami perkembangan dan kemajuan karena ada dialog keilmuan yang terbangun di masyarakat, namun di sisi lain bisa jadi ini adalah indikasi bahwa orang yang mengerti tentang Ilmu falak sekaligus fiqih atau hukum Islam sudah jarang di temui di Indonesia. Dalam tulisan ini akan dikaji tentang penyebab terjadinya perbedaan penetapan awal bulan itu terjadi dan bagaimana solusi yang tepat untuk menyatukan perbedaan tersebut.

\section{Akar Perbedaan Penetapan Awal Bulan}

Permasalahan penentuan awal bulan qamariyah utamanya menjelang datangnya bulan Ramadlan, Syawwal dan Dzulhijjah yang digunakan umat Islam dalam penentuan beribadah menjadi problem klasik, 
bisa juga polemik, wacana aktual dan masalah besar. Dikatakan klasik karena sejak zaman permulaan Islam, dan semasa perkembangan Islam selanjutnya di kalangan sahabat, tabi'in, para ulama dan pakar hukum Islam selalu menjadikan ketiga awal bulan tersebut sebagai pembahasan dalam penetapannya sampai sekarang. Disebut polemik karena para ulama dan ahli fiqih (pakar hukum Islam) dalam kitab-kitab fiqihnya pada bab puasa dan penentuan awal bulan Ramadhan, Syawwal dan Dzulhijah selalu membahas secara panjang lebar dan termasuk berbagai perbedaan pendapat masing-masing. Dianggap wacana aktual dan faktual karena berbagai pakar disiplin ilmu baik ahli hisab rukyat, astronom dan ahli lainnya ikut serta membahas dan membicarakan penentuan ketiga awal bulan tersebut dan upaya penyatuannya yang di ekspos oleh media secara terbuka. Dikatakan masalah menjadi besar karena negara-negara berpenduduk mayoritas Islam, para ulama ahli fiqih, ahli hisab rukyat dan astronomi maupun cendekiawan muslim sedunia membahasnya dan berupaya sungguh-sungguh mencari jalan dan cara penyatuannya sampai sekarang melalui forum-forum pertemuan pakar falak dan astronomi sedunia ${ }^{2}$.

Ada beberapa faktor penyebab terjadinya perbedaan dalam menetapkan awal bulan (Ramadlan, Syawal dan Dzulhijjah) :

Pertama, adanya perbedaan penafsiran dan pemahaman perintah memulai dan mengakhiri puasa, apakah boleh memulai dan mengakhiri puasa dengan rukyat semata atau dengan perhitungan (hisab), dan apakah rukyat tersebut masalah ta'abbudi atau ta'aqquli. Perbedaan tersebut melahirkan dikotomi hisab rukyat dengan adanya klaim ijtihadiyah 1 : Rukyat bersifat qath'i sehingga menentukan, sedangkan hisab bersifat dzhanniy sehingga hanya pendukung atau diabaikan. Dan klaim ijtihadiyah 2: hisab bersifat qath' $i$ sehingga menentukan, sedangkan rukyat bersifat dzhanniy sehingga hanya pendukung atau diabaikan.

Kedua, adanya perbedaan sistem dan metode perhitungan (hisab). Metode perhitungan awal bulan qamariyah di Indonesia tumbuh dan berkembang sangat pesat dan menghasilkan berbagai macam sistem/ metode hisab lebih dari 35 sistem perhitungan. Secara umum sistem hisab tersebut dibagi menjadi dua yakni urfi dan hakiki. Sistem urfi adalah sistem perhitungan yang sangat sederhana tanpa mempertimbangkan posisi dan kondisi hilal dan matahari. Metode ini

2 Khotib Asmuni dkk, Dasar-Dasar Ilmu Falak, Makalah Diklat Hisab Rukyat di UIN Malang Januari 2011 hanya bermain di angka-angka yang bersifat prediktif. Sistem perhitungannya didasarkan atas peredaran rata-rata bulan mengelilingi bumi dan ditetapkan secara konvensional. Sistem ini sama seperti sistem kalender syamsiyah bilangan hari pada tiap-tiap bulan berjumlah tetap kecuali bulan tertentu pada tahun-tahun tertentu jumlahnya lebih panjang satu hari. Sistem ini pada dasarnya tidak dapat digunakan untuk menentukan awal bulan qamariyah sebagai awal Ramadlan, Syawal dan Dzulhijjah karena menurut sistem ini umur bulan Sya'ban dan Ramadlan adalah tetap, yaitu 29 untuk bulan Sya'ban dan 30 hari untuk Ramadlan ${ }^{3}$.

Di Indonesia masih ada masyarakat yang menggunakan pedoman sistem ini untuk penetapan awal bulan Ramadlan, Syawal dan Dzulhijjah, yang tergolong sistem ini adalah kalender jawa Islam atau Islam jawa asapon dan aboge. Adapun sistem hakiki perhitungannya dengan mempertimbangkan terjadinya ijtima,${ }^{4}$ serta posisi dan kondisi hilal dan matahari, dengan kata lain sistem perhitungannya didasarkan pada peredaran bulan dan bumi yang sebenarnya sehingga menurut sistem ini umur setiap bulan tidaklah konstan dan juga tidak beraturan, melainkan tergantung pada posisi hilal setiap awal bulan. Metode hakiki ini terbagi menjadi tiga : (a) Hisab hakiki taqribi, yang termasuk dalam sistem ini adalah Sullam al-Nayirain, Fath Rauf al- Manan, Tadzkirah al-Ikhwan, AlQawaid al-Falakiyah, Risalah al-Qamarain, Hisab Qath'i, Risalah al-Falakiyah, Risalah Syams al-Hilal, dan lain-lain. (b) Hisab hakiki tahqiqi yang termasuk dalam sistem ini adalah Al-Mathla al Said, Manahijul Hamidiyah, Al-Khulashah Al-Wafiyah, Muntaha Naij Aqwal, Badi'ah Al-Mitsal, Hisab Hakiki, Menara Kudus, Nur al- Anwar, Ittifaq Dzat al-Bayn, dan lainlain, (c) Hisab hakiki kontemporer yang termasuk dalam sistem ini adalah New Comb, Islamic Calander, Jean Meuus, Almanac Nautika, Astronomical Almanac, Ephemeris Hisab Rukyat, Ascript, Astroinfo, Mooncal, Mawaqit dan lain-lain.

\footnotetext{
Suziknan Azhari, Ilmu Falak Teori dan Praktik, (Yogyakarta:Lazuardi, 2001), h. 93-95

4 Ijtima' atau iqtiran (Konjungsi) adalah suatu peristiwa saat bulan dan matahari terletak pada posisi garis bujur yang sama bila dilihat dari arah timur ataupun arah barat. Namun sebenarnya bila diamati ternyata jarak antara kedua benda langit tersebut berkisar sekitar 50 derajat. Dalam keadaan ijtima' hakikatnya masih ada bagian bulan yang mendapatkan pantulan dari sinar matahari, yaitu bagian yang menghadap ke bumi. Namun kadangkala karena tipisnya hal tersebut tidak dapat dilihat dari bumi karena ketika ijtima' bulan berdekatan letaknya dengan matahari. Lihat Suziknan Azhari, Ensiklopedi Hisab Rukyat, (Yogyakarta : Pustaka Pelajar, 2008), h. 93-94 secara astronomi umum ijtima' adalah new moon (bulan baru) namun dalam ilmu fala atau hisab rukyat ijtima' adalah indikator awal akan terjadinya pergantian bulan qamariyah.
} 
Ketiga adanya perbedaan pedoman atau kriteria mernulai tanggal satu dan posisi hilal awal bulan. Aliran Ijtima', aliran ini berpendapat bahwa peristiwa Ijtima' merupakan awal terjadinya pergantian bulan tanpa memperhitungkan dan mempertimbangkan posisi hilal. Sehingga aliran ini tidak mempermasalahkan hilal dapat dilihat atau tidak. Pendapat ini mengadopsi dari teori astronomi murni yang menyatakan terjadinya new moon (bulan baru) terjadi sejak saat matahari dan bulan dalam keadaan Ijtima'(konjungsi). Dari teori ini kemudian terbagibagi lagi menjadi beberapa pendapat berdasarkan atas kriteria yang lebih spesifik, antara lain :

Pertama, Ijtima' Qabl al-Ghurub mempunyai arti bahwa adanya awal bulan atau bulan baru jika terjadinya Ijtima' sebelum matahari tenggelam walaupun hilal masih di bawah ufuq atau terbenam terlebih dahulu dari pada matahari. Berdasarkan kondisi tersebut, Ijtima'nya terjadi sebelum masuk terbenam, malam harinya sudah masuk tanggal 1 bulan baru namun jika terjadinya ijtima' setelah matahari tenggelam maka malam harinya masih tanggal 30 bulan yang sedang berlangsung.

Kedua, Ijtima' Qabl al-Fajr adalah kriteria pergantian bulan yaitu ketika peristiwa ijtima' (konjungsi) terjadi sebelum fajar. Ketika hal ini terjadi maka sejak terbit fajar pada hari tersebut sudah masuk tanggal satu bulan baru. Dan sebaliknya jika ijtima' terjadi setelah terbit fajar maka pagi harinya masih tanggal 30 bulan yang masih berlangsung. Teori ini mengenyampingkan terhadap posisi bulan atau hilal.

Ketiga, Ijtima' Qabl Nishf al-Nahar adalah terjadinya ijtima' (konjungsi) sebelum tengah hari merupakan kriteria yang digunakan untuk menentukan terjadinya pergantian bulan. Artinya jika terjadi demikian maka mulai hari itu adalah bulan baru dan apabila terjadinya ijtima sesudah tengah hari maka hari itu masih tanggal 30 bulan yang berlangsung.

Keempat, ijtima' Qabl Nishf al-Layl yaitu kriteria bulan baru berdasarkan ijtima' (konjungsi) terjadi sebelum tengah malam. Jika terjadi demikian maka sejak malam itu sudah masuk tanggal 1 bulan baru dan jika sebaliknya, manakala ijtima' (konjungsi) terjadi setelah lewat tengah malam maka malam itu masih tanggal 30 bulan yang berlangsung.

\section{Ijtima' dan Wujud al-Hilal}

Kriteria penentuan awal bulan qamariyah dengan ketentuan jika setelah terjadi ijtima' (konjungsi), bulan terbenam setelah terbenamnya matahari, artinya bulan muda atau hilal wujud (ada) sebelum matahari tebenam maka pada malam hari tersebut dinyatakan sebagai awal bulan qamariyah, tanpa melihat berapapun sudut ketinggian (altitude) bulan muda atau hilal saat matahari terbenam.

\section{Imkan al-Rukyat}

Imkan al-Rukyat adalah kriteria penentuan awal bulan (kalender) Hijriyah yang ditetapkan berdasarkan atas posisi hilal seberapa mungkin bisa dirukyat. Kriteria yang digunakan adalah sebagai berikut: (a) Pada saat matahari terbenam, ketinggian (altitude) bulan di atas cakrawala minimum $2^{\circ}$, dan sudut elongasi (jarak lengkung) bulan-matahari minimum $3^{\circ}$, dan atau, (b) Pada saat bulan terbenam, usia bulan minimum 8 jam, dihitung sejak ijtima'.

Di Indonesia, secara tradisi pada petang hari pertama sejak terjadinya Ijtima' (yakni setiap tanggal 29 pada bulan berjalan), Pemerintah Republik Indonesia dalam hal ini Kementerian Agama melalui Badan Hisab Rukyat (BHR) melakukan kegiatan rukyat (pengamatan visibilitas hilal), dan dilanjutkan dengan sidang Itsbat, yang memutuskan apakah pada malam tersebut telah memasuki bulan (kalender) baru, atau menggenapkan bulan berjalan menjadi 30 hari. Hal ini sesuai kesepakatan dari musyawarah Menteri Agama Brunei Darussalam, Indonesia, Malaysia, dan Singapura (MABIMS), dan dipakai secara resmi untuk penentuan awal bulan Hijriyah pada Kalender Resmi Pemerintah. Di samping metode Imkan alRukyat versi Pemerintah atau MABIMS di atas, juga terdapat kriteria lainnya yang serupa, dengan besaran sudut/angka minimum yang berbeda.

Dengan adanya perbedaan metode dan keabsahan laporan rukyat, sebagian keabsahan rukyat harus sesuai dengan metode hisab dan sebagian lainnya tidak harus sesuai dengan metode hisab, yang penting orang yang melapor rukyat tersebut adil, jujur, benar dan disumpah oleh hakim.

Dengan adanya perbedaan wilayah (wilayat alhukmi) atau wilayah global, maka wilayat al-hukmi pun ada perbedaan seberapa luas cakupan wilayah apakah satu negara, atau satu kota atau satu wilayah regional misalnya asia tenggara dan lain-lain. Sementara wilayah global pun memiliki perbedaan pendapat apakah penetapannya mengikuti Saudi Arabia, dengan alasan lahirnya Islam dan ka'bah kiblat umat Islam berada di Mekah, atau tidak harus mengikuti Saudi Arabia pokoknya di manapun hilal muncul atau terlihat itu bisa dijadikan acuan masuknya awal bulan.

Karena perbedaan siapa yang berhak menetapkan penetapan ketiga awal bulan tersebut, pemerintah atau 
boleh yang lainnya. Karena perbedaan keyakinan masing-masing pengikut aliran dan atau organisasi terhadap institusi atau lembaga atau orang yang dianggap panutan oleh mereka terlepas apakah mengerti ilmu falak atau tidak.

Dari beberapa faktor tersebut yang paling memberikan dampak dan dianggap pokok adalah adanya perbedaan interpretasi terhadap nash terkait tentang penentuan awal bulan yang kemudian memicu munculnya faktor-faktor yang lain.

Terkait dengan perbedaan penentuan 3 awal bulan di atas ada data yang perlu kita cermati bersama untuk dijadikan bahan refrensi dan renungan untuk mencarikan solusi penyatuan penetapan awal bulan tersebut (Tabel I) $:^{5(}$

5 T. Djamaluddin, Menuju Kreteria Hisab Ruyat Indonesia, Presentasi dalam Seminar Nasional HISSI 15 Januari 2010

\section{Penyatuan Penetapan Awal Bulan}

Dalam upaya penyatuan penetapan awal bulan setidaknya ada dua pendekatan yang bisa dilakukan :

\section{Pendekatan Dialektis Metodologis}

Dalam rangka upaya penyatuan penetapan awal bulan qamariyah khususnya Ramadlan, Syawal dan Dzulhijjah, sebenarnya semenjak lahirnya perbedaan tersebut sudah diadakan kompromi dan perumusan metode yang bisa disepakati oleh semua pihak baik dari kelompok hisab, rukyat, wilayah global atau wilayat al-hukmi namun sampai detik ini tidak ada kata sepakat terhadap metode yang digunakan saat ini. Selama masing-masing pihak tetap mengedepankan egonya maka sulit untuk mempetemukannya dalam satu metode yang bisa disepakati atau bahkan tidak akan mungkin bisa ketemu satu kata sepakat hatta alakhirah.

\section{Tabel I}

\begin{tabular}{|c|c|c|c|}
\hline \multirow{2}{*}{ Tahun } & \multicolumn{3}{|c|}{ Irtifa' / Tinggi Hilal } \\
\hline & Ramadlan & Syawal & Dzulhijjah \\
\hline 1422 / 2001-2002 & $\begin{array}{c}1,7 \\
\text { rawan perbedaan }\end{array}$ & 6,3 & $\begin{array}{c}2,5 \\
\text { rawan perbedaan }\end{array}$ \\
\hline 1423 / 2002-2003 & 7,7 & $\begin{array}{c}1,2 \\
\text { rawan perbedaan }\end{array}$ & $\begin{array}{c}1,3 \\
\text { rawan perbedaan }\end{array}$ \\
\hline 1424 / 2003-2004 & 11,8 & 6,1 & 8,5 \\
\hline 1425 / 2004-2005 & 3,4 & 10,3 & 13,8 \\
\hline $1426 / 2005$ & 10,0 & 3,3 & 4,7 \\
\hline $1427 / 2006$ & 8,8 & $\begin{array}{c}0,9 \\
\text { rawan perbedaan }\end{array}$ & 10,6 \\
\hline $1428 / 2007$ & 8,5 & $\begin{array}{c}0,7 \\
\text { rawan perbedaan }\end{array}$ & 7,4 \\
\hline $1429 / 2008$ & 6 & $-0,7$ & -4 \\
\hline $1430 / 2009$ & -1 & 6 & 6 \\
\hline $1431 / 2010$ & 3 & -2 & $\begin{array}{c}1,7 \\
\text { rawan perbedaan }\end{array}$ \\
\hline $1432 / 2011$ & 7,5 & $\begin{array}{c}1,8 \\
\text { rawan perbedaan }\end{array}$ & 7,1 \\
\hline $1433 / 2012$ & $\begin{array}{c}2 \\
\text { rawan perbedaan }\end{array}$ & $-4,3$ & $-2,4$ \\
\hline 1434 / 2013 & $\begin{array}{c}0,7 \\
\text { rawan perbedaan }\end{array}$ & 4,2 & 3,6 \\
\hline $1435 / 2014$ & $\begin{array}{c}0,8 \\
\text { rawan perbedaan }\end{array}$ & 4,1 & $\begin{array}{c}0,8 \\
\text { rawan perbedaan }\end{array}$ \\
\hline
\end{tabular}


Namun, walaupun demikian usaha untuk mencari metode dan kreteria yang tepat untuk bisa diterima oleh semua pihak dan tetap dalam koridor syar'iyah (tuntunan agama) dan ilmiah harus tetap dilakukan. Salah satu usaha yang dilakukan oleh pemerintah dalam hal ini Kementerian Agama RI melalui BHR (Badan Hisab Rukyat) untuk menjembatani perbedaan tersebut adalah dengan membuat kreteria yang disebut Imkan al-Rukyat (visibilitas Hilal). Pada bulan Dzulqa' dah 1418 bertepatan dengan maret 1998 para ulama ahli hisab dan rukyah dan para perwakilan organisasi kemasyarakatan Islam mengadakan musyawarah tentang kreteria imkan al-rukyah untuk Indonesia di mana keputusan musyawarahnya ditetapkan pada hari senin tanggal 7 Jumadil Akhir $1418 \mathrm{H} / 28$ september 1998. Adapun hasil keputusannya adalah sebagai berikut ${ }^{6}$ (a) Penentuan awal bulan qamariyah didasarkan pada sistem hisab hakiki tahkiki dan atau rukyah, (b) Penentuan awal bulan qamariyah yang terkait dengan pelaksanaan ibadah mahdhah yaitu awal Ramadan, Syawal dan awal Dzulhijjah ditetapkan dengan memperhitungkan hisab hakiki tahkiki dan rukyah, (c) Kesaksian rukyah dapat diterima apabila ketinggian hilal 2 derajat dan jarak ijtima ke ghurub matahari atau usia hilal minimal 8 jam, (d) Kesaksian rukyah hilal tidak dapat diterima apabila ketinggian hilal kurang dari dua derajat maka awal bulan ditetapkan berdasarkan istikmal, (e) Apabila ketinggian hilal 2 derajat atau lebih, awal bulan dapat ditetapkan, (f) Kriteria Imkan al-Rukyah tersebut di atas akan dilakukan penelitian lebih lanjut. Menghimbau kepada seluruh pimpinan organisasi kemasyarakatan Islam untuk mensosialisasikan keputusan ini, (g) Dalam melaksanakan sidang istbat, pemerintah mendengarkan pendapat-pendapat dari organisasi kemasyarakatan Islam dan para ahli.

Keberadaan kriteria Imkan al-Rukyah di Indonesia sebenarnya mengadopsi dari hasil keputusan Komite Penyelarasan Rukyah dan Taqwim Islam MABIMS (Menteri Agama Brunei, Indonesia, Malaysia dan Singapura). Kreteria Imkan al-Rukyah ini merupakan tawaran Pemerintah dalam rangka menyatukan perbedaan pemikiran dalam hisab rukyah di Indonesia (dalam hal ini penetapan awal bulan Ramadan, Syawal dan Dzulhijjah).

Perlunya kreteria Imkan al-rukyat ini bertujuan antara lain untuk ${ }^{7}$; Pertama, bagi ahli rukyat,

\footnotetext{
6 Ahmad Izzuddin, Problematika Hisab Rukyat di Indonesia, makalah dipresentasikan pada Pendidikan keterampilan Khusus Bidang Hisab Rukyat, Ditjen Pendis Departemen Agama RI 2007

7 T. Djamaluddin, Menuju Kreteria Hisab Rukyat Indonesia. Presentasi
}

untuk mengeliminasi kemungkinan salah lihat Hilal. Seperti pada kasus 1998/1418: Berdasarkan kriteria MABIMS PBNU menolak kesaksian Cakung dan Bawean yang hilalnya terlalu rendah (tinggi bulan 54', umur 3 jam). Kasus 2006/1427: Berdasarkan kriteria imkan rukyat Lajnah Falakiyah NU tidak mengambil Cakung dan Madura karena hilal teralu rendah $\sim 1$ derajat

Kedua, bagi ahli hisab, untuk bisa menentukan masuk awal bulan.atau belum dari hasil perhitungan posisi hilal. Seperti kasus 1998/1418: Muhammadiyah berdasarkan kriteria wujudul hilal menetapkan Idul Fitri 29 Januari 1998. Persis mengikuti kriteria MABIMS menetapkan Idul Fitri 30 Januari 1998. Kasus 2006/1427: Muhammadiyah berdasarkan kriteria wujudul hilal menetapkan Idul Fitri 23 Oktober 2006. Persis berdasarkan kriteria wujudul hilal di seluruh Indonesia menetapkan Idul Fitri 24 Oktober 2006.

Walaupun keputusan ini telah ditetapkan secara bersama-sama namun tetap saja masih berbeda-beda dalam menetapkan awal bulan. Pendekatan dengan cara ini memang membutuhkan proses dan waktu yang lama dan perlu menjadi catatan bahwa faktor utama keberhasilan melalui pendekatan ini adalah saling terbuka dan memahami terhadap pemikiran dan pendapat dari semua pihak dengan mengenyampingkan egoisme kelompok masing-masing.

\section{Pendekatan Single Authority}

Solusi yang paling mudah dan cepat terwujudnya penyatuan penetapan 3 awal bulan tersebut adalah dengan menggunakan pendekatan single authority atau adanya kesepakatan otoritas tunggal dalam penetapan 3 awal bulan tersebut. Dalam hal ini pemerintahlah yang dianggap dan bisa memilki otoritas untuk menetapan 3 awal bulan tersebut melalui Kementerian Agama. Tanpa membatasi ruang pemikiran dan pendapat masing-masing kelompok, pemerintah tidak boleh bersikap otoriter dalam keputusannya menetapkan 3 awal bulan tersebut maka perlu ada prosedur yang harus dilalui yakni adanya sidang terbuka yang dihadiri oleh semua elemen dan kelompok Islam di Indonesia yang menghasilkan keputusan yang disepakati bersama, ini sebenarnya sudah dilakukan oleh pemerintah dengan menggelar sidang Istbat sebelum menetapkan 1 Ramadlan, Syawal dan Dzulhijjah. Dari hasil sidang Itsbat inilah kemudian pemerintah menetapkan awal bulan tersebut, namun

dalam Seminar Nasional HISSI 15 Januari 2010 
menjadi aneh ketika tidak semua kelompok mematuhi dan melaksanakan keputusan tersebut. Inilah yang perlu dipahami oleh semua terutama para ahli dan pakar falak dan khususnya masyarakat umum bahwa ketika terjadi perselisihan atau perbedaan maka pemerintah memiliki otoritas untuk menyelesaikannya sesuai dengan kaidah fiqh :

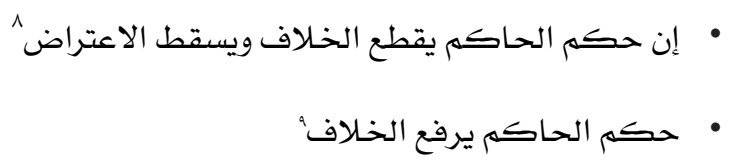

Agar masyarakat tidak dibingungkan dengan perbedaan maka perlu ada kesepakatan bahwa satusatunya yang berhak menetapkan 1 Ramadalan, Syawal dan Dzulhijjah adalah Pemerintah dan satusatunya yang harus diikuti. Masyarakat akan merasa lebih tenang dan khusyu' ketika menjalankan ibadah ketika terwujudnya kesatuan dan persatuan dalam penetapan awal bulan dan inilah yang diharapkan. Ketenangan dan kekhusyu'an ini merupakan maslahah yang semestinya direngkuh dan diwujudkan dari pada mengedepankan pendapat: perbedaan adalah rahmat (ikhtilaf ummati rahmah). Dan akan lebih baik bersatu dari pada berbeda karena keluar dari perbedaan adalah dicintai atau disunnahkan sesuai dengan kaidah :

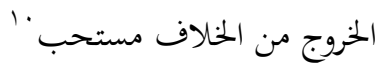

Dan perlu dipahami pula oleh semua bahkan oleh pemerintah sendiri bahwa pemerintah dalam

8 Ali ibn Muhammad al-Amidiy, al-Ihkam fi Ushul al-Ahkam, juz.4, (Beirut : Dar al-Kitab al-Arabiy, 1404 H), h. 313

9 Lihat Wahbah Zuhaili, Al-Fiqh al-Islamiy wa Adillatuh, juz 3 (Damaskus: Dar al-Fikr, tt), h.39

10 Abd al-Rahman ibn Abi Bakr al-Suyuthi, Al-Asybah a al-Nadha'ir, (Beirut : Dar al-Kutub al-Ilmiyah, 1403H), h.136.

\section{Daftar Pustaka}

al-Amidiy, Ali ibn Muhammad. 1404. al-Ihkam fi Ushul al-Ahkam, Beirut : Dar al-Kitab alArabiy.

Amin, Murtadlo, 2008. Ilmu Falak Praktis. Malang : UIN press.

al-Suyuthi, Abd al-Rahman ibn Abi Bakr. 1403. AlAsybah a al-Nadha 'ir, Beirut : Dar al-Kutub alIlmiyah.

Azhari, Susiknan. 2001. Ilmu Falak Teori dan Praktek. Yogyakarta : Lazuardi.

Azhari, Susiknan. 2008. Ensiklopedi Hisab Rukyat, Yogyakarta : Pustaka Pelajar. menetapkan awal bulan tidaklah tanpa dasar atau ngawur dan tentunya tidak ada tendensi politis apapun dalam keputusannya semua berdasarkan atas kesepakatan dalam sidang itsbat yang dihadiri oleh perwakilan dari semua elemen dan kelompok Islam di Indonesia yang hasilnya bisa dipertanggungjawabkan secara syar'iah maupun ilmiah.

\section{Kesimpulan}

Upaya untuk mencari metode dan kriteria awal bulan qamariyah yang bisa diterima oleh semua kelompok dan tetap dalam koridor syar'i dan keilmuan lewat pendekatan dealitis metodologis mutlak harus tetap dilakukan namun itu membutuhan proses dan waktu yang lama oleh karena itu sembari menunggu hasil dari proses tersebut maka percepatan penyatuan penetapan awal bulan harus segera dilakukan lewat pendekatan single authority dimana pemerintah yang wajib diikuti karena memiliki otoritas tunggal dalam menetapkan awal bulan. Dengan mempertimbangan ri'ayatul maslahah yakni kekhusyu'an dan ketenangan dalam menjalankan ritual keagamaan di masyarakat harus jauh diuatamakan. Kita tidak bisa menutup mata ketika di masyarakat muslim arus bawah mengalami kebingungan dan kegamangan dengan adanya perbedaan tersebut. Dengan demikian bahwa hukumnya wajib bagi masyarakat (umat Islam Indonesia) untuk mengikuti keputusan pemerintah dalam penetapan 1 Ramadlan, Syawal dan Dzulhijjah dengan pertimbangan: (1) Pemerintah adalah otoritas tunggal dalam menetapkan awal bulan ketika terjadi perbedaan, (2) Ri'ayatul maslahah mewujudkan ketenangan dan kekhusyu'an dalam menjalankan ibadah, (3) Keluar dari perbedaan adalah disunnahkan atau dicintai (agama).

Departemen Agama RI. 1981. Almanak dan Rukyat. Jakarta : Proyek Pembinaan badan Peradilan Agama.

Departemen Agama RI. 1983/1984. Pedoman Teknik Rukyat. Jakarta : Proyek Pembinaan Badan Peradilan Agama.

Departemen Agama RI. 1997. Pedoman Perhitungan Awal Bulan Qamariyah. Jakarta : Proyek Pembinaan badan Peradilan Agama.

Djamaluddin, T, Menuju Kreteria Hisab Rukyat Indonesia, (Presentasi dalam Seminar Nasional HISSI di UIN Jakarta 15 Januari 2010). 
Izzuddin, Ahmad. 2007. Fiqih Hisab Rukyah. Jakarta : Erlangga.

Karim, Abdul. 2006. Mengenal Falak. Semarang: Intra Pustaka Utama.

Khazin, Muhyiddin. 2004. Ilmu Falak. Yogyakarta : Buana Pustaka.

Khazin, Muhyiddin. 2006. Kamus Ilmu Falak,
Yogyakarta : Biana Pustaka.

Nawawi, Salam. 2001. Ilmu Falak. Surabaya : Aqabah.

Nawawi, Salam. 2004. Rukyat Hisab. Surabaya : Diantama.

Zuhaili, Wahbah. tt. Al-Fiqh al-Islamiy wa Adillatuh. Damaskus: Dar al-Fikr. 